Joseph R. Chapel*

South Orange

\title{
Ferdinand Ebner: na początku było słowo
}

\section{Wstęp: Stowo a rozwój człowieka}

Około 800 lat temu cesarz Fryderyk II chciał się dowiedzieć, który język w rzeczywistości jest pierwotnym językiem dzieci; którym językiem mówiłyby one instynktownie, gdyby nikt na nie uprzednio nie oddziaływał: czy mówiłyby ,językiem hebrajskim, który był najstarszym, czy greckim, czy łacińskim, czy może językiem rodziców, którzy dali im życie"l. Zatem cesarz zaprojektował pewien eksperyment; wiele nowonarodzonych dzieci zostało zabranych matkom zaraz po urodzeniu, dzieciom zapewniono najlepszą możliwą opiekę: jedzenie, ubrania, mycie i kąpiele itp. Był tylko jeden warunek: opiekunom zabroniono wydawać jakiekolwiek dźwięki w obecności dzieci; nie mogli mówić „gu” czy „ga”, w ogóle ani słowa - w żadnym języku - aby cesarz mógł dowiedzieć się, którym językiem dzieci zaczną mówić instynktownie. A więc, którym językiem zaczęły mówić? Otóż cesarz nigdy się tego nie dowiedział, ponieważ wszystkie dzieci poddane temu

* Ks. prof. dr Joseph R. Chapel jest profesorem teologii moralnej w Seton Hall University, New Jersey, USA, od 2014 roku pracuje jako ojciec duchowny w Casa Santa Maria w Rzymie. Adres: Casa Santa Maria, Via dell'Umiltà, 30, 00187 Rome (RM) Italy; e-mail: joseph.chapel@shu.edu.

${ }^{1}$ Salimbene, Chronicle, red. F. Bernini (Bari: G. Laterza e Figli, 1942), cyt. za The Portable Medieval Reader, red. i tłum. James Bruce Ross, Mary Martin McLaughlin (New York: Viking Press, 1949), 366-367. 
eksperymentowi zmarły, pomimo tego, że były otoczone najlepszą opieką! Dlaczego tak się stało?

Znamy takie historie jak Tarzan czy Greystoke, władca matp - są to historie o „dzikich” czy „powtórnie zdziczałych” dzieciach, które w jakiś sposób przeżyły porzucenie lub zagubienie w dżungli, a następnie zostały wychowane, bez ludzkiej ingerencji, przez małpy czy wilki. Pojawia się pytanie: jaki rodzaj umiejętności językowych te „dzikie” czy „powtórnie zdziczałe" dzieci rozwinęły w sobie, gdy zostały wprowadzone, zazwyczaj w okresie dojrzewania lub później, do ludzkiego społeczeństwa? Odpowiedź jest taka, że po upływie określonego czasu, już w bardzo młodym wieku, możliwości rozwoju języka okazywały się bardzo ograniczone. Dzieci te nie mogły stać się w pełni ludźmi na poziomie języka, jeśli nie były wychowane od początku w prawdziwie „ludzkim” otoczeniu² . Dlaczego tak się dzieje?

Kilka lat temu przeprowadzono interesujące badania dotyczące poziomu inteligencji u dzieci (pomiaru dokonywano u dzieci w wieku 3 lat). Badania te pokazały, że: ,język mówiony ma zadziwiający wpływ na rozwój dziecięcego mózgu. Liczba słów, którą dziecko słyszy każdego dnia, jest najistotniejszym czynnikiem prognostycznym pozwalającym na przewidywanie późniejszego poziomu inteligencji, sukcesów w szkole oraz kompetencji społecznych"3. Jednakże tylko niektóre dzieci spośród tych, które słyszały bardzo wiele słów, odznaczały się wyższą inteligencją. Dlaczego?

Kończąc ten wątek, odniosę się do moich dwóch niedawnych doświadczeń w Salwadorze: w domu dziecka, który często tam odwiedzam, po raz pierwszy została otwarta przychodnia lekarska, w której pracowali lekarze-wolontariusze. W pierwszym dniu prawie każde dziecko udawało ból głowy lub brzucha, aby zobaczyć lekarza... Dlaczego? Niedaleko tego miejsca, w domu opieki dla osób starszych, w którym przebywali zazwyczaj smutni podopieczni, pojawili się młodzi studenci uczący się pielęgniarstwa i innych medycznych umiejętności. Mieli oni spędzić w domu opieki tydzień, aby nauczyć się, jak wprowadzać do dokumentacji historie chorób pacjentów. Studenci rozmawiali ze starszymi pacjentami przez cały ten okres. Zauważyłem, że podopieczni tym razem byli bardzo szczęśliwi i radośni... Dlaczego?

Dlaczego dzieci w eksperymencie cesarza Fryderyka II zmarły? Dlaczego Tarzan i Greystoke, władca małp i inne „dzikie dzieci” nie były w sta-

2 Susanne Katherina Langer, Philosophy in a New Key. A Study in the Symbolism of Reason, Rite, and Art (Cambridge: Harvard University, 1974), 107-108.

3 Sandra Blakeslee, „Making Baby Smart: Words Are the Way”, International Herald Tribune, 19 kwietnia 1997: 1n. 
nie nabyć umiejętności posługiwania się mową i funkcjonować na poziomie w pełni ludzkim? Dlaczego działo się tak, że tylko kilkoro dzieci spośród tych, które słyszały mnóstwo słów, miało wyższy poziom inteligencji? Dlaczego dzieci w domu dziecka udawały, że były chore? Dlaczego starsze osoby w domu opieki były takie szczęśliwe, gdy młodzi studenci przeprowadzali z nimi wywiad medyczny? Otóż, wrócimy później do tych praktycznych sytuacji i pytań, które w związku z nimi postawiłem. W tym punkcie powiedzmy, że kluczem do zrozumienia każdej sytuacji jest obecność lub nieobecność autentycznego słowa!

Z punktu widzenia praktyki życia społecznego, na przykład edukacji lub opieki medycznej, wszystko w pewnym sensie sprowadza się do pytania, czy jest możliwe, aby skutecznie wykorzystać słowa i język, posługując się nimi jedynie „mechanicznie”, jako abstrakcyjnymi, obiektywnymi narzędziami? $\mathrm{Z}$ drugiej strony, trzeba zadać pytanie, czy do skuteczności słowa potrzeba czegoś więcej niż takiej „mechaniki”, abstrakcji i obiektywności? Kiedy słowo staje się wyjątkowe, osobiste oraz zaczyna angażować studenta i pacjenta jako ,podmioty”?

\section{Na początku było słowo}

Jest coś wyjątkowego w słowie i w języku, który leży u podstaw naszej ludzkiej tożsamości. W Europie aktualnie ma miejsce odrodzenie zainteresowania dziełami „,filozofów dialogicznych”. Najbardziej znanym przykładem jest książka Ja i Ty Martina Bubera ${ }^{4}$, która umożliwia gruntowne zrozumienie, że do własnej samoświadomości dochodzimy tylko w autentycznej relacji z drugą osobą, w przeciwieństwie do obcowania z bezosobowością świata „Ja” i „To”: „Gdy mówi się «Ty», wypowiada się jednocześnie słowo «Ja» z pary słów «Ja-Ty»... Podstawowe wyrażenie «Ja-Ty» można wypowiedzieć tylko całą swoją istotą. Podstawowego wyrażenia «Ja-To» nigdy nie można wypowiedzieć całą istotą"5.

Relacja Ja-Ty jest ryzykowna, ponieważ Ja zwraca się do Ty całym soba, bez przyjmowania pozycji obronnej. W przeciwnym razie staje się ona relacją Ja-To, ponieważ część własnego Ja jest powstrzymywana przed wejściem w dialog, podobnie jak dzieje się to u obserwatora. W tym samym czasie Ty musi spełnić warunki bycia ,innym”, to znaczy posiadającym wol-

${ }^{4}$ Martin Buber, Ja i Ty. Wybór pism filozoficznych (Warszawa: Pax, 1992).

5 Tamże, 39. 
ność do nieprzewidywalnej odpowiedzi. Jeśli odpowiedzi są przewidywalne, jeśli Ja zapytuje, jaki rodzaj wrażenia wywiera na Ty, wówczas relacja jest relacją do To, nie do Ty.

Takie spotkanie Ja-Ty jest łaską od Boga, który sprawia, że spotkanie to jest w ogóle możliwe: „Każde pojedyncze Ty jest prześwitem ku niemu. Przez każde pojedyncze Ty podstawowe słowo zagaduje wieczne Ty..." Najważniejszym elementem myśli Bubera jest to, iż Bóg jest „wiecznym Ty” lub ,absolutnym Ty”, do którego mówimy w drugiej osobie, raczej niż $o$ którym mówimy w trzeciej osobie.

Takie rozumienie dialogu Martin Buber zawdzięcza austriackiemu myślicielowi dialogicznemu Ferdinandowi Ebnerowi (1882-1931), który jest znany w Europie przede wszystkim za sprawą swojego dzieła Stowo i realności duchowe (Das Wort und die geistigen Realitäten) ${ }^{7}$, wydanego po raz pierwszy w 1921 roku i następnie przetłumaczonego na wiele języków, $\mathrm{w}$ tym na język polski ${ }^{8}$. Ebner dostrzegał w słowie coś fundamentalnego dla ludzkiego istnienia i dlatego jego punktem wyjścia jest pierwszy wers we wstępie do Ewangelii według św. Jana: „Na początku było słowo” (J 1, 1).

Użycie powyższych słów, w intencji Ebnera, nie miało na celu sformułowania teologicznego twierdzenia, mimo że Ebner był osobą wierząca; nie chodziło również o wypowiedzenie twierdzenia filozoficznego, gdyż nie postrzegał on siebie jako filozofa. Raczej opisywał siebie jako Bedenker des Wortes - „przemyśliwującego słowo" ". Ebner postrzegał te słowa z Ewangelii według św. Jana jako rzeczywisty fakt, hermeneutyczny klucz do rzeczywistości „słowa” jako takiego, podstawę ludzkiej egzystencji. Ponieważ całe

6 Tamże, 85.

${ }^{7}$ Dzieło Ebnera jest zatytułowane Das Wort und die geistigen Realitäten. Pnuematologische Fragmente. Po raz pierwszy zostało wydane w Innsbrucku w 1921 roku. Ostatnie wydanie zostało przygotowane przez Richarda Hörmanna (Wiedeń 2009). Harold Johnson Green, The Word and the Spiritual Realities: A Translation of and Critical Introduction to Ferdinand Ebner's "Das Wort und die geistigen Realitäten" and a Comparison with Martin Buber's "Ich und Du" (Evanston: Diss. Northwestern University, 1980).

8 Tłumaczenie włoskie: La parola e le realtà spirituali. Frammenti pneumatologici, tłum. P. Renner, red. S. Zucal (Milano: Cinisello Balsamo 1998); thumaczenie hiszpańskie: La palabra y las realidades spirituales. Fragmentos pneumatológicos, thum. J. M. Garrido (Madrid: Caparrós, 1995); tłumaczenie polskie: Stowo i realności duchowe. Fragmenty pneumatologiczne, thum. K. Skorulski (Warszawa: Wydawnictwo IFiS PAN, 2006); thumaczenie angielskie w przygotowaniu: The Word and the Spiritual Realities tłum. Harold Johnson Green, red. Joseph Chapel.

9 Taki napis polecił też zamieścić na swoim nagrobku na cmentarzu w Gablitz niedaleko Wiednia. 
swoje dorosłe życie Ebner przepracował jako nauczyciel, jego myśl znalazła pełne zastosowanie przede wszystkim w edukacji, niemniej jest doceniana i wykorzystywana również w wielu innych dyscyplinach.

Przypatrzmy się, jakie wątki wyłaniają się z myśli Ebnera.

Po pierwsze, dla Ebnera język jest cudem pochodzącym od Boga! Ludzka mowa jest składową ludzkiego istnienia; tylko ludzie „posiadają słowo”. Pisząc o tym, Ebner zauważa: „Chodzi więc o możliwość bycia osobą «mówiącą», lecz także - znowu dzięki temu, że ma on [człowiek - przyp. mój J. Ch.] słowo i sens dla tego słowa - możliwość bycia osobą "zagadniętą», bycia Ty" ${ }^{10}$. Fakt, że w przeciwieństwie do zwierząt możemy porozumiewać się i rozumieć siebie nawzajem, jest dość szokujący i cudowny. Tylko w słowie i języku jest możliwe, żeby „Ja” spotkało „Ty”; ta relacja i samoświadomość może zaistnieć, zaś to słowo może się ujawnić w Logosie, który Ebner rozumie zarówno jako logos filozofii i jako Logos Ewangelii według św. Jana: „Na początku było Słowo”, które pośredniczy między Bogiem a człowiekiem i „staje” pomiędzy Ja i Ty. Za pośrednictwem Jezusa, Logosu, jest możliwe zwrócenie się do Boga w ludzkim Ty.

Po drugie, jako istoty ludzkie, ponieważ „posiadamy słowo”, musimy „mówić słowem”. Nasze współczesne społeczeństwo kładzie duży nacisk na indywidualizm z upodobaniem do ,monologu”, jednak to nie zmienia faktu, iż istoty ludzkie są ontycznie przygotowane do „dialogu”; samorealizacja dokonuje się tylko w relacjach $\mathrm{Ja}-\mathrm{Ty}^{11}$.

Po trzecie, zagadnienie „Ja-Ty” jest niezbędne do zrozumienia znaczenia istnienia, po to, aby słowo, które musi zostać wypowiedziane, było „autentycznym słowem". Ja nie może zostać odnalezione samoistnie, dlatego musi spojrzeć na Ty, podczas gdy fałszywe Ja próbowałoby zawładnąć Ty jak przedmiotem władzy. Tak więc fałszywe Ja nie zwraca się do Ty, ale postrzega Ty jako przedmiot; fałszywe Ja odnosi się do Ty w trzeciej osobie. To jest centralny element Ebnerowskiej krytyki myśli i filozofii idealistycznej: rzeczywistość, prawda, tożsamość osobista nie są ideami ani też nie mają być odnalezione w ideach, wypowiadanych w trzeciej osobie, lecz muszą

${ }^{10}$ Ebner, Stowo, 12.

${ }_{11}$ To, że musimy mówić słowem, otwiera nam drogę ku zasadom teorii ,języka performatywnego". Nie każda mowa jedynie przekazuje informacje (np. „książka kosztuje trzy euro”), niektóre akty mowy zmieniają rzeczywistość i ujawniają swoje „działanie” poprzez wypowiedzenie; to są słowa, które są ,performatywne (niebędące realną wypowiedzią)", to znaczy, te słowa „robią to, co mówią” (np. „biorę cię za żonę”). Patrz: John Langshaw Austin, How to Do Things With Words (Cambridge: Harvard University Press, 1975). 
być wypowiedziane w drugiej osobie. Zatem należy odrzucić Kartezjańskie cogito, gdyż nie może być ono odnalezione w istnieniu samego Ja czy też udowodnione przez myślenie jednoosobowe; ujawnia się ono natomiast w relacji do Ty.

Po czwarte, słowo daje życie, życie dialogu w relacji, tak więc nawet $\mathrm{w}$ ciszy słowo jest autentyczne i kierowane do partnera w dialogu. Możemy wycofać się z tego spotkania w „samotność Ja”, w nieautentyczny świat idei lub „snu o duchu”, rodzaj snu, z którego współczesna kultura sama nie może się wybudzić - może to jednak uczynić poprzez czekanie i reagowanie na Boże wezwanie. Ebner zauważa, że „[c]hrześcijaństwo nie jest idea. Doprowadziło ono raczej idealizm do refleksji nad sobą, a przez to usunęło go zarazem ze świata - tak jak sen rozwiewa się w nicość, gdy człowiek zda sobie sprawę, że śni" "12. Dopóki to przebudzenie nie nadejdzie, człowiek pozostaje zamknięty na drugiego. Takie ,zamykanie się na Ty” jest istotą grzechu. Prawdziwe Ja jest zawsze w odniesieniu do Ty. Budzimy się ze „snu o duchu”, otwierając się na Ty, które pojawia się obiektywnie w "słowie” i subiektywnie przepełnia się miłością w autentycznej relacji: mężczyzna i kobieta spotykają Boga - wieczne Ty - u bliźnich, i spotykają swoich bliźnich u Boga. Ta miłość, zrodzona ze słowa, przepełnia się we wspólnocie przejawiając się najpierw w rodzinie i osobistych stosunkach, a następnie przenosząc się na zewnątrz - do szkoły, pracy i życia zawodowego.

Po piąte, istnieje tutaj powiązanie między myślą a słowem, które może zostać nazwane „napięciem komunikacyjnym”; słowa dostarczają napięcia naszym myślom, napięcia, które jest impulsem czy też pragnieniem, aby porozumiewać się. Zatem słowo doprowadza myśl na skraj dialogu i pozwala, aby myśl zakorzeniła się w istocie osoby. W tym znaczeniu słowo czyni ludzi wolnymi, ponieważ poprzez słowo możemy ustalić dystans pomiędzy naszymi przeczuciami a ich znaczeniem. Zwierzęta muszą słuchać instynktów; my, istoty ludzkie, ponieważ możemy nazywać i wyrażać nasze doświadczenia słowami, możemy ustanowić odległość perspektywy, a następnie dokonywać wyborów w wolności. W tym znaczeniu Słowo czyni nas wolnymi w słowie. Ebner pisze, że ,[m]oże to być też przebudzenie do rzeczywistości ducha, prowadzące człowieka od jego związania z duchem do wolności. Musi się on jedynie wystrzegać jakiegokolwiek nadużycia wolności, które wrzuciłoby go nieuchronnie z powrotem w jego związanie z duchem"13.

\footnotetext{
12 Ebner, Stowo, 223.

13 Tamże, 217.
} 


\section{Ludzkie bycie jako zależne od słowa i miłości}

Otóż bez szczegółowego wyjaśnienia myśli Ebnera trudno jest zrozumieć całą problematykę słowa, języka i dialogu w ujęciu austriackiego myśliciela. W tej chwili w wielu krajach, także w Polsce, pojawia się coraz więcej tekstów na temat filozofii Ebnera, więc czytelnik może pogłębić swoje teoretyczne analizy podejścia Ebnerowskiego. Dla mnie jest ważne, aby pokazać, w jaki sposób ta myśl może pomóc w zrozumieniu tych zdarzeń, o których napisałem na początku mojego tekstu.

W eksperymencie cesarza Fryderyka oczywiście wszystkie dzieci zmarły! Podobnie po II wojnie światowej w domach dziecka dla uchodźców i później w sierocińcach dla dzieci chorych na AIDS w Rumuni zgony występowały z tego samego powodu: nie było tam nikogo, kto by mówił do dzieci! Nasza tożsamość jako ludzi ostatecznie dociera do nas za sprawą słowa. Powodem jest niezwykłość ludzkiej umiejętności, to jest „wyrażania się" w języku i poprzez język. Moja tożsamość zaczyna być kształtowana od pierwszych pieszczot oraz ,gu-gu” i ,ga-ga” mojej mamy i taty oraz tych, którzy mnie kochają. Chociaż moja tożsamość będzie ostatecznie różna od tożsamości moich rodziców, moja tożsamość - moja zdolność, aby powiedzieć: ,ja jestem”, pochodzi od tych, którzy mnie kochają. Różnimy się od zwierząt i staliśmy się całkowicie ludzcy - to znaczy żyjemy, pracujemy, kochamy, żyjemy w społeczeństwie i wspólnocie - w języku i poprzez język. W słowie i poprzez słowo dochodzimy do naszej tożsamości.

W końcu moje ,ja jestem” oznacza, że ktoś inny powiedział do mnie: „ty jesteś”; że ostatecznie ten Inny, jak sugerują myśliciele dialogiczni, to Bóg. Bóg, który ujawnia swoją własną tożsamość Mojżeszowi, mówiąc „Ja jestem" - z tego właśnie wywodzi się rozumienie własnej tożsamości Narodu Wybranego! Mówiąc „Ja jestem”, Bóg również mówi „Ty jesteś”.

Gdy rozważymy implikacje tego wszystkiego, uświadomimy sobie trudności w myśli Kartezjusza. Powiedział on Cogito ergo sum - „myślę, więc jestem". Sednem tych słów było to, iż jedynym sposobem, aby na pewno wiedzieć, że istnieję, jest dostrzeżenie siebie myślącego. Tymczasem wydaje się, że mogę myśleć, ponieważ posiadam dar, jakim jest język, dar słowa; przekazano mi go w rodzinie i za sprawą tych, którzy mnie kochają: „Jestem..., więc myślę!”.

I od Tarzana i jego przyjaciół możemy nauczyć się, że ten dar nie jest dostępny długo, nie jest ,do wzięcia” w każdym czasie! Mowa jest wyjątkową ludzką zdolnością. Tak, szympansy i inne zwierzęta mogą czasem zostać 
nauczone naśladowania słowa lub zdania, ale tylko ludzie są w stanie nabyć zdolność abstrakcyjnego myślenia i prawdziwy język. Prawdziwe użycie słowa oznacza bycie zdolnym do mówienia o rzeczach, które są nieobecne tu i teraz, w zasięgu mojego wzroku. To jest umiejętność, która może być nabyta tylko przez ludzi i, co ważne, ta umiejętność może być dana i otrzymana w pierwszych latach życia dziecka. Język nie jest instynktowny, trzeba się go nauczyć. Ten okres, w którym można to zrobić, nie trwa wiecznie, po okresie dojrzewania człowiek może rozwinąć w sobie tylko ograniczone możliwości językowe i ograniczone kompetencje społeczne. Tarzan, Greystoke i ich towarzysze przegapili ten okres w bardzo bolesny sposób! Tak oto zwięźle podsumował to jeden z pisarzy: „Najczystsze zwierzęce wezwanie miłosne, ostrzeżenie czy gniew, dzieli od najmniejszego, banalnego ludzkiego słowa cały dzień aktu stworzenia" 14 .

A co z małymi dziećmi, które przystępowały do testu inteligencji? Wszystkie były we właściwym „oknie wieku”, aby nauczyć się mówić. Dlaczego zatem niektóre z nich przyswoiły sobie tak wiele słów, a inne bardzo mało? Otóż okazało się, że w badaniu ujawniły się pewne fakty, które zaskoczyły badaczy: te dzieci, które zostały pozostawione w zasadzie same sobie, siedząc przed telewizorem, oglądając programy edukacyjne, nauczyły się bardzo niewielu słów. Badanie ujawnia, że: „... słowa muszą pochodzić od uważnych, zaangażowanych istot ludzkich. Na tyle, na ile można było to ustalić, radio i telewizja nie działaja..."15. Okazuje się, że przypadkowe słowa, słuchane w pojedynkę, nie wystarczaja, musi im towarzyszyć miłość muszą one być wypowiadane przez tych, którzy kochają. Mamy tu do czynienia ze współzależnością: miłość jest potrzebna, aby spotkać słowo.

Wróćmy do sierot, które symulowały chorobę w przychodni medycznej: otrzymywały one czasem mniej indywidualnej uwagi i uczucia niż, jako dzieci, potrzebowały lub pragnęły - udawały, że są chore, ponieważ chciały, aby lekarze poświęcili czas na rozmowę z nimi i poznali je! Lekarze, którzy opatrywali dzieci, czerpali przyjemność z tych spotkań i śmiali się, gdy opowiadali tę historię. Oni rozumieli, że fizyczne spotkanie w trakcie leczenia może być nieprzyjemne w sensie intymnym, ale często może stać się bardziej przyjemne. Dzieje się to za sprawą prawdziwego zaangażowania pacjenta w autentyczny dialog, w którym spotyka się pacjenta jako osobę, a nie jako ,przedmiot" - tylko jako przypadek choroby.

14 Langer, Philosophy, 103.

15 Blakeslee, „Making”, 1 (podkreślenie moje, J. Ch.). 
Podobnie działo się pośród osób starszych w domu opieki społecznej. Ludzie ci często byli bardzo smutni, ale niekiedy stawali się bardzo radośni - było tak podczas wywiadu medycznego. Oni naprawdę lubili studentów pielęgniarstwa, opiekunów medycznych i przyszłych lekarzy, nie z powodu opieki medycznej, ale z tego powodu, że ci młodzi ludzie z nimi rozmawiali! Kiedy zapytałem studentów o cel ich pracy z osobami starszymi, wyjaśnili, że właściwie nie chodziło o to, aby dotrzeć do historii choroby - była ona już znana - ale raczej, aby usłyszeć historię życia każdej starszej osoby! O życiu bowiem i o jego historii czasami się zapomina! Wykładowcy przygotowujący tych młodych lekarzy i pielęgniarzy do pracy wyjaśniali im, że celem tego ćwiczenia było nauczenie się budowania dialogu z pacjentami, budowania prawdziwych relacji - w ten sposób pacjent mógł pomyślnie przystapić do leczenia, które było mu potrzebne. Właśnie to było tak ważne dla pacjentów, iż lekarze i pielęgniarki poznali ich jako ludzi - jako osoby indywidualne, jako osoby ważne - z doniosłymi historiami życiowymi! Ważne było, aby najpierw wymienić się $\mathrm{w}$ autentycznym dialogu, dzięki temu później starsza osoba mogła czuć się komfortowo podczas badania lekarskiego lub w trakcie dalszego leczenia. Autentyczne słowo, dialog, ludzkie spotkanie i relacja nie są tylko koniecznym ,wstępnym” krokiem, ale powinny być przede wszystkim elementem leczenia przez cały czas - jeśli pomoc medyczna ma być naprawdę skuteczna i naprawdę ludzka!

\section{Zakończenie: Mówić slowem autentycznym}

Każda z tych życiowych historii ukazuje nam: po pierwsze, że nabywamy naszą tożsamość od słowa, tylko w społeczeństwie; po drugie, tylko ludzie „posiadają słowo”; i po trzecie, możemy przyswoić sobie słowo, kiedy jesteśmy kochani! Stajemy się i jesteśmy rozpoznawani za pomocą autentycznego słowa.

Kilka razy wspomniałem o „autentycznym słowie”. Filozofowie dialogiczni głoszą, że ponieważ „posiadamy słowo”, musimy „mówić słowem”; takie jest nasze powołanie jako ludzi. Ale również filozofowie ci mówią nam, że słowo musi być słowem ,autentycznym”, co jest możliwe tylko wtedy, gdy mówimy do innej osoby w drugiej osobie, mówiąc „do Ty”, a nie mówiąc w trzeciej osobie, co może ,uprzedmiotowić” Ty.

Tym sposobem możemy powiedzieć, że nie odnosimy się do Boga, mówiąc o Nim w trzeciej osobie, ale właściwie w drugiej osobie: mówimy do Niego. Podobnie w naszych osobistych ludzkich relacjach, naszej pracy jako 
nauczycieli i jako specjalistów medycznych, możemy uprzedmiotowić drugą osobę, mówiąc $o$ niej w trzeciej osobie, zamiast w drugiej osobie: mówiąc do niego czy do niej - wiarygodnie: ,ja jestem"; ... ,ty jesteś”.

Podsumowując, wracamy do pytania postawionego na początku: jaka jest rola słowa i tak naprawdę jaki rodzaj słowa jest odpowiedni dla rozwoju uczniów w placówce oświatowej i dla rozwoju pacjentów w palcówce medycznej?

W pewnym stopniu w tę kwestię uwikłany jest zdrowy rozsądek: w edukacji z pewnością należy zachować pewną „obiektywność” i dystans, aby sprawdzić i jasno ocenić możliwości każdego ucznia. Z drugiej strony, nawet proste doświadczenie pokazuje, że dzieci w klasie szkolnej nie rozwijają się, jeśli nie czują pozytywnych emocji i szacunku jako ludzie, osoby indywidualne.

Również w medycynie jest wymagana podobna „obiektywność” i dystans, aby rzetelnie sprawdzać i jasno zakomunikować stan zdrowia każdego pacjenta. Z drugiej strony, odpowiednie ,podejście do pacjenta” jest istotne dla wyników stosowanego leczenia: jest mniej prawdopodobne, że pacjent, który jest traktowany jako „przedmiot” i po prostu jako przykład choroby, zaufa i zaangażuje się w leczenie, niż w przypadku pacjenta, który jest traktowany $\mathrm{z}$ miłosierdziem jako indywidualna osoba, jako osoba $\mathrm{z}$ historią, na drodze życia.

Kończąc spytajmy, jaka struktura intelektualna wzmacnia ten „zdrowy rozsądek"? Intencją tego tekstu nie było podanie recepty, odpowiedzi na użycie „słowa” w tym miejscu, ale podsunięcie pewnej fundamentalnej myśli, która może przy odrobinie szczęścia udzielić wsparcia w opracowaniu wymogów dla realnych rozwiązań i metod, które każdorazowo będzie można dostosować do własnej pracy.

\section{Ferdinand Ebner: In the Beginning Was the Word (Summary)}

In the article the author presents a few events, from the past and today, the actual and literary stories, related to the use of language and proposes their dialogical interpretation. The basis for the interpretation is Ferdinand Ebner's thought, and particularly his concept of the word as a force enabling the development of the human being. In the entire text there are clear theological references, first of all to Saint John's Gospel and its idea of Logos. The author points out that any encounter between human persons contains in itself a certain spiritual potential, which may 
be actualized only thanks to love stemming from God. Thus the word reveals its profound religious and therapeutic power.

Key words: Ebner; the word; love; I and Thou; education; health care.

\section{Ferdinand Ebner: na początku było słowo (Streszczenie)}

W artykule autor przedstawia kilka wydarzeń, z przeszłości i współczesności, faktycznych i literackich, związanych z użyciem języka i proponuje ich dialogiczną interpretację. Podstawą dla tej interpretacji jest myśl Ferdinanda Ebnera, a zwłaszcza jego koncepcja słowa jako siły umożliwiającej rozwój człowieka. W całym tekście powracają wyraźne odniesienia teologiczne, szczególnie do Ewangelii św. Jana i obecnej w niej koncepcji Logosu. Autor podkreśla, że każde spotkanie między osobami zawiera w sobie pewien duchowy potencjał, który może być zrealizowany tylko dzięki miłości mającej swoje źródło w Bogu. W ten sposób słowo ujawnia swoją głęboką moc religijną i terapeutyczną.

Słowa kluczowe: Ebner; słowo; miłość; Ja i Ty; edukacja; opieka zdrowotna.

\section{Bibliografia}

Austin, John Langshaw. How to Do Things With Words. Cambridge: Harvard University Press, 1975.

The Portable Medieval Reader, red. i thum. James Bruce Ross, Mary Martin McLaughlin. New York: Viking Press, 1949.

Blakeslee, Sandra. „Making Baby Smart: Words Are the Way”. International Herald Tribune, 19 kwietnia 1997: 1.

Buber, Martin. Ja i Ty. Wybór pism filozoficznych. Warszawa: Pax, 1992.

Ebner, Ferdinand. Stowo i realności duchowe. Fragmenty pneumatologiczne, thum. Krzysztof Skorulski. Warszawa: Wydawnictwo IFiS PAN, 2006.

Green, Harold Johnson. The Word and the Spiritual Realities: A Translation of and Critical Introduction to Ferdinand Ebner's "Das Wort und die geistigen Realitäten" and a Comparison with Martin Buber's "Ich und Du". Evanston: Diss. Northwestern University, 1980.

Langer, Susanne Katherina. Philosophy in a New Key. A Study in the Symbolism of Reason, Rite, and Art. Cambridge: Harvard University, 1974.

Salimbene. Chronicle, red. F. Bernini. Bari: G. Laterza e Figli, 1942. 
